\title{
Click-chemistry approach to azacycloalkene monosulfonyl diamines: synthesis and computational analysis of the reaction mechanism $\dagger+$
}

\author{
Alessandro Contini* and Emanuela Erba \\ Received 27th July 2012, Accepted 7th September 2012 \\ DOI: $10.1039 / \mathrm{c} 2 \mathrm{ra21592f}$ \\ The cycloaddition reaction of the morpholino enamines of $N$-methylpiperidone and $N$-methyl \\ tropinone with sulfonylazides was exploited, leading to a click-chemistry approach to uncommon \\ azacycloalkene monosulfonyl diamines in good yields. A computational model for the key step \\ decomposition of the triazoline intermediate was then realized by DFT calculations. The model \\ explains the observed reaction outcome and leads to a new interpretation of the decomposition \\ mechanism for 5-amino-1,2,3-triazolines.
}

\section{Introduction}

Vicinal diamines frequently appear as structural units in organic molecules of biological and medicinal interest, as well as in auxiliary groups or ligands for catalytic processes. ${ }^{1}$ Moreover it was demonstrated that monotosylated diamine complexes of $\mathrm{Ru}(\mathrm{II})$ form highly enantioselective catalysts for ketone reductions. ${ }^{2}$ In particular, our group is currently interested in synthetic methodologies to achieve novel sulfonamide derivatives which have been found useful as potential inhibitors of protein Rac1. ${ }^{3}$

For those reasons, in this paper we describe a facile and versatile synthetic method to obtain azacycloalkene-monosulfonyl-diamines from accessible starting materials.

Our group studied for a long time cycloaddition reactions and the subsequent rearrangement of the cycloadducts of aryl and sulfonyl azides with enamines of various aldehydes and linear or cyclic ketones. ${ }^{4}$ In particular, when sulfonyl azides were used, the primary unstable dihydrotriazole cycloadduct underwent a spontaneous transformation and two main products were obtained: 2-alkyl-sulfonylamidine $\mathbf{1}$ by nitrogen loss and C-5 substituent transposition and the sulfonylformamidine 2 by alkyl diazomethane loss (Scheme 1).

The obtained amidines were extensively used as syntones in heterocycle synthesis. ${ }^{5}$ Aiming to obtain new synthetically useful starting materials, a number of carbonylic compounds have been used. It is known that the nature of the starting carbonyl

Dipartimento di Scienze Farmaceutiche - Sezione di Chimica Generale e Organica "Alessandro Marchesini", Università degli Studi di Milano,

Centro Interuniversitario di Ricerca sulle Reazioni Pericicliche e Sintesi di Sistemi Etero e Carbociclici, Via Venezian, 2120133 Milano, Italy.

E-mail: alessandro.contini@unimi.it; emanuela.erba@unimi.it;

Fax: +39.02.503.14476; Tel: +39.02.503.14475

$\uparrow$ This work is dedicated to our mentor and friend, Prof. D. Pocar, for his 50 year long exploration of triazoline chemistry.

\$ Electronic supplementary information (ESI) available: Further computational details, Cartesian coordinates, energies and thermochemical corrections for all the stationary points, NMR spectra of compounds 5ad and 7a-d. See DOI: 10.1039/c2ra21592f reactant appears to rule the outcome of the reaction, and cyclic ketones containing a nitrogen atom showed an unexpected behaviour. ${ }^{6}$ Consequently, one aim of this work was to thoroughly investigate the behaviour of alkylpiperidones and tropinones as the carbonylic reactant. Moreover, due to the peculiar regiochemical results herein obtained, an in-depth computational study of the reaction mechanism was performed. The results were in perfect agreement with the experiments and provided the evidence for a new interpretation of the mechanism of 5-amino-1,2,3-triazoline decomposition and rearrangement.

\section{Results and discussion}

\section{Chemistry}

The reaction between morpholino enamine of 1-methyl-4piperidone $\mathbf{3}$ and tosyl azide $\mathbf{4 a}$ was initially investigated. By performing the reaction at room temperature in methylene dichloride as the solvent, we observed a rapid nitrogen development, but any attempt to isolate the components of the

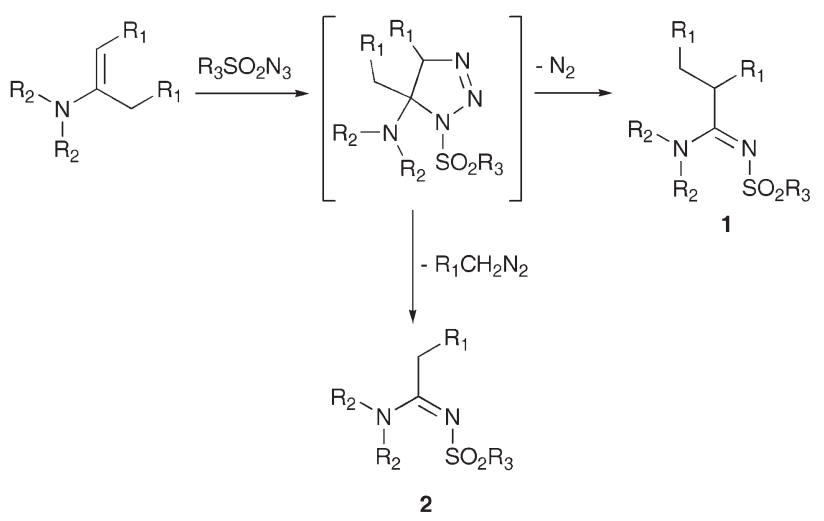

Scheme 1 General reaction scheme for the cycloaddition of enamines with sulfonyl azides. 
complex crude mixture failed. Indeed, the crude changed during the work-up procedures and subsequent chromatography purification gave discouraging results. The main evidence was the absence of expected amidine $\mathbf{1}$ or formamidine 2. Even by working at lower temperature, comparable results were obtained. However, starting from freshly distilled enamine in appropriate conditions of solvent and temperature (i.e. diethyl or diisopropyl ether, depending on the product's solubility, and 5$10{ }^{\circ} \mathrm{C}$ ) the pure compound 5a precipitated from the solution and was isolable in good yields. This compound was stable for several days at room temperature and for several months at $0{ }^{\circ} \mathrm{C}$. The structure of tosylamide 5a was deduced from the reported spectroscopic and spectrometric data. Indeed, the molecular weight supplied by mass analysis showed the loss of nitrogen and the ${ }^{1} \mathrm{H}$ NMR showed the presence of the tosyl group and two different multiplets corresponding to the morpholine moiety. The exchangeable proton, two methyl groups and complex multiplets in the aliphatic zone were also evident. ${ }^{13} \mathrm{C}$ NMR spectra showed the presence of three methylene signals and two quaternary carbons at 129.0 and $126.0 \delta$ in addition to the tosyl and morpholine signals. ${ }^{1} \mathrm{H}$ NMR spectra in $\mathrm{CDCl}_{3}$ also showed a complex multiplet at 5.75-5.80 $\delta$ associated to enaminic $\mathrm{CH}$ of tautomer D (see Scheme 3). However, this characteristic multiplet disappeared by changing the NMR solvent to DMSO, suggesting a stabilization of the $\mathbf{5} \mathbf{a}$ form.

Encouraged by those interesting results, we drove to extend this scheme to other starting materials to verify the reaction trend and the repeatability of the results. The selected enamines were the morpholino enamines of 4-methylpiperidone 3 and of tropinone $\mathbf{6}$, while the chosen sulfonylazides were tosylazide $\mathbf{4 a}$, p-nitrosofolylazide $\mathbf{4 b}$, styrylsulfonylazide $\mathbf{4 c}$, $o$-nitrosulfonylazide 4d and phenylmethanesulfonylazide 4e (Scheme 2).

In all cases the products were obtained in good yields in accordance with the proposed scheme. An in-depth study of NMR HSQC, COSY and NOESY spectra of 7d allowed us to unequivocally confirm the proposed structure. All signals were separable and identified in ${ }^{1} \mathrm{H}$ and ${ }^{13} \mathrm{C}$ NMR at 500 and $125 \mathrm{MHz}$, respectively. So the nOe effect between NCH-1 at $3.49 \delta$ and morpholino $\mathrm{CH}_{2} \mathrm{~N}$ at $2.55 \delta$ confirmed the $\mathrm{C} 2$ position of morpholine. Another observation was useful to explain the reaction steps. When the ${ }^{13} \mathrm{C}$ spectra of a concentrated solution of $7 \mathbf{d}$ ( $50 \mathrm{mg}$ of $\mathbf{7 d}$ in $1 \mathrm{~mL}$ of $\left.\mathrm{CDCl}_{3}\right)$ was recorded, the first 50 scans only showed signals associated with the imino form $\mathrm{C}$ (see Scheme 3). Instead the ${ }^{13} \mathrm{C}$ spectra recorded after $10 \mathrm{~h}$ of sample preparation only showed signals associated with the enamino form 7. This fact suggested the imino form $\mathrm{C}$ as the initial reaction product, which subsequently tautomerizes (Scheme 3 ).

\section{Computational investigation of the reaction mechanism}

Save for a theoretical study for the proton-induced decomposition of 1,2,3-triazoline and 1-methyl-1,2,3-triazoline, ${ }^{7}$ to our knowledge no detailed theoretical studies for the thermal decomposition and rearrangement of 4- and 5-substituted triazolines have been reported in the literature. A well formulated mechanistic hypothesis, although not supported by theoretical calculations, for the decomposition of bicyclic triazolines obtained by the reaction of benzylazide with different enones has been proposed by Aubè and coworkers. ${ }^{8}$

Although the reported mechanism concerned bicyclic triazolines bearing an alkyl group at the 7a position, its generalization to the 7-morpholino substituted triazolines herein described, as depicted in Scheme 4, appears to be legitimate.

Indeed, the triazolines $\mathrm{A}$, through an initial ring opening, could provide a zwitterion intermediate $\mathrm{B}$ which could evolve by either ring contraction (path $a$ ) or [1,2] shift of the morpholino group (path $b$ ) and consequent nitrogen loss. The zwitterion intermediate could exist in two different conformations, B1 and B2: while conformer B1 leads to 1-2 bond migration onto the leaving diazonium group in an antiperiplanar fashion, migration of the morpholino group in $\mathrm{B} 2$ onto the axial diazonium species results in formation of imine $\mathrm{C}$ which could tautomerize to 5 and D (see Scheme 3).

Previously reported decompositions of triazolines obtained by the reaction of tosylazide with 4-cyclohexenylmorpholine $(\mathrm{X}=$ $\mathrm{CH}_{2}$ ), ${ }^{4 a}$ only provided the ring contraction product 1 (path $a$ ). On the other hand, the herein reported reactions $\left(\mathrm{X}=\mathrm{NCH}_{3}\right)$ only provided diamino products 5,7 (or the corresponding $\mathrm{C}$ and $\mathrm{D}$ tautomers) deriving from the migration of the morpholino group (path $b$ ).
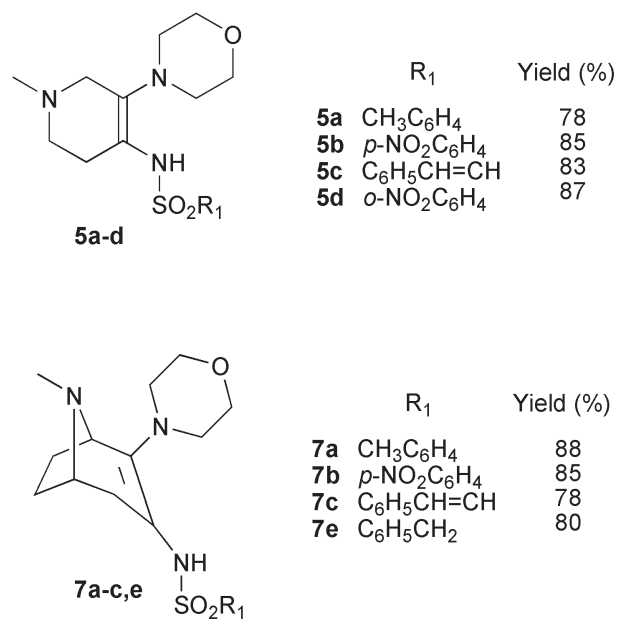

Scheme 2 Reaction scheme for azacycloalkene-monosulfonyl-diamines 5 and 7. Reagents and contitions: (i) $\mathrm{Et}_{2} \mathrm{O}\left(i \operatorname{Pr}_{2} \mathrm{O}\right.$ for $\left.\mathbf{5 b}\right), 20{ }^{\circ} \mathrm{C}, 15$ min. 


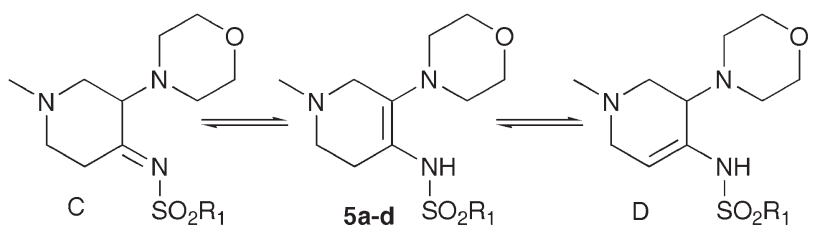

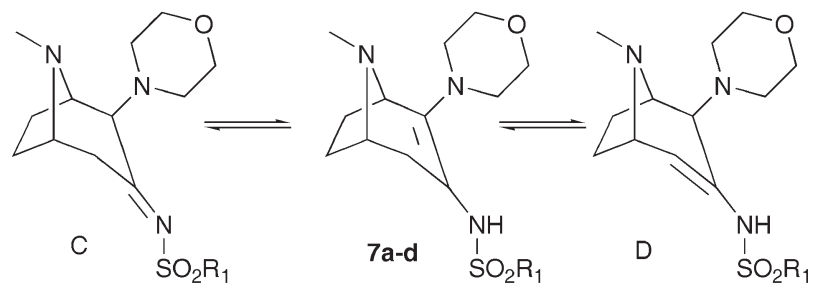

Scheme 3 Tautomeric forms of products 5, 7 .

Starting from the results herein reported and considering our interest in modeling reaction mechanisms, ${ }^{9}$ we decided to perform a computational mechanistic study by means of Density Functional Theory (DFT). The mPW1B95 functional, ${ }^{10}$ coupled with the $6-31+G(d, p)$ basis set, was chosen for all calculations as in precedent works of our group it proved to be highly reliable when compared with other common functionals. ${ }^{9 d, e}$ All calculations have been performed in the gas phase and in solution, where the solvent effect was considered for both geometry optimizations and Intrinsic Reaction Coordinates (IRCs) analyses by means of the conductor-like polarizable continuum model (CPCM) for diethyl ether. ${ }^{11}$ Unless differently specified, the following discussion is referred to solution phase results.

The decomposition of triazolines $\mathrm{A}_{\mathrm{N}}$ (from 1-methylpiperidin4-one, hereafter referred as the "aza" model) and $\mathrm{A}_{\mathrm{C}}$ (from cyclohexanone, hereafter referred as the "carbo" model), where $\mathrm{Ar}=\mathrm{Ph}$, were chosen as representative reaction models. The following discussion, unless differently specified, refers to both the "aza" and "carbo" models.

Starting from the mechanistic hypothesis of Scheme 4, we initially evaluated the difference in stability between zwitterion conformations B1 and B2 as their energy difference might be responsible for the observed outcome. However, for both the

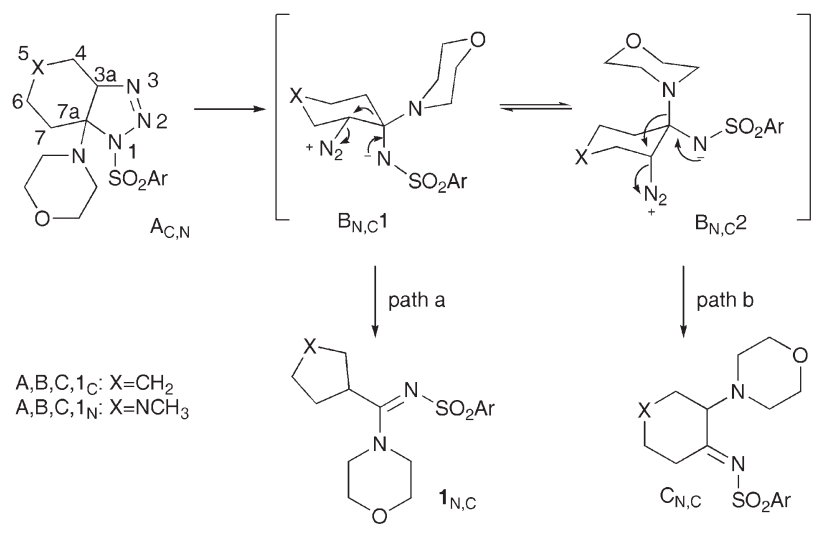

Scheme 4 Stepwise mechanistic hypothesis for bicyclic 1,2,3 triazolines. "aza" and "carbo" models, the B1 conformer was the most favored, being 2.3 and $3.1 \mathrm{kcal} \mathrm{mol}^{-1}$ more stable, respectively.

This result suggests that the reaction outcome might be controlled at the transition state level, then the relative stability between transition states for paths $a$ and $b$ could rule the reaction outcome. For this reason, structures corresponding to triazolines A, zwitterions B and products $\mathbf{1}$ and C, were fully optimized. Starting from the most stable conformation of triazolines A, the location of the transition states (TSs) leading to zwitterions B was attempted by slightly lengthening the N1-N2 bond distances.

In both the "aza" and "carbo" models, the corresponding TS$\mathrm{A}_{\mathrm{N}} 1$ and $\mathrm{TS}-\mathrm{A}_{\mathrm{C}} 1$ presented $\mathrm{N} 1-\mathrm{N} 2$ and $\mathrm{C} 3 \mathrm{a}-\mathrm{N} 3$ ( $d 1$ and $d 2$, accordingly to Fig. 1), bond distances both increased with respect to the corresponding distances in triazolines $\mathrm{A}(\Delta d 1=$ $1.066 \AA, \Delta d 2=0.400 \AA$ and $\Delta d 1=1.043 \AA, \Delta d 2=0.382 \AA$ for the "aza" and "carbo" models, respectively), thus suggesting that the nitrogen molecule might be eliminated in a concerted manner.

To confirm or refuse this hypothesis, an IRC analysis, ${ }^{12}$ which locates the lowest energy path connecting reactants to TSs and TSs to products, was performed starting from TS-A 1 and TS$\mathrm{A}_{\mathrm{C}} 1$. In both cases the IRC analyses confirmed the direct transformation of triazolines $\mathbf{A}$ into the final products $\mathbf{1}$ without the obtainment of any zwitterionic structure that could be considered a stationary point along the potential energy surface (PES) (Fig. 2).

This result gives weight to the hypothesis that triazolines might decompose through a pericyclic mechanism, involving a sigmatropic [1,2] shift of the alkyl (path $a$ ) or morpholino (path $b)$ groups accompanied by nitrogen loss. The two different paths $a$ and $b$ would then originate from the conformations A1 or A2 of the corresponding triazoline, accordingly to Scheme 5.

It should be noted that, analogously to what is observed for the hypothesized zwitterion intermediates, conformation A1 is always preferred for triazolines also $\left(\Delta G_{\mathrm{A} 2-\mathrm{A} 1}=3.2\right.$ and $1.1 \mathrm{kcal}$ $\mathrm{mol}^{-1}$ for "aza" and "carbo" models, respectively) and so the preference toward paths $a$ or $b$ should be exclusively determined at the transition state level. This hypothesis could be confirmed
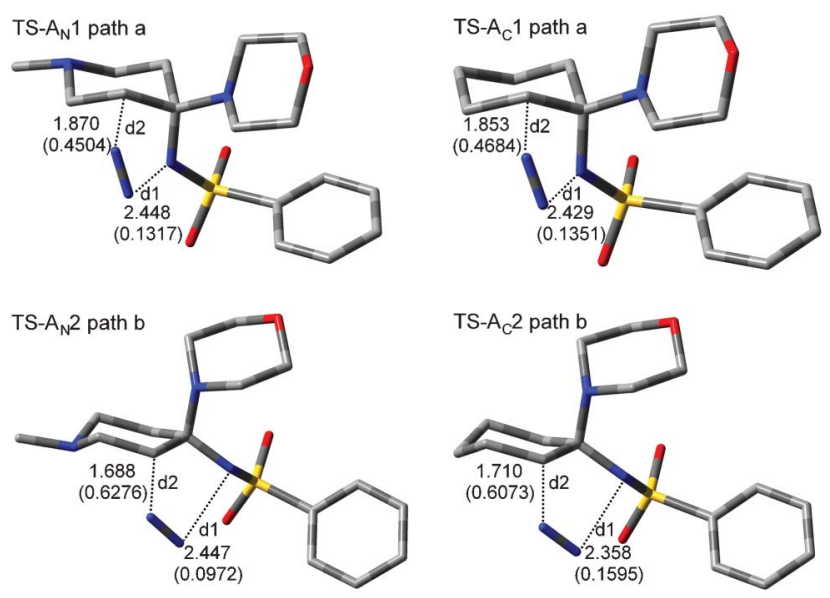

Fig. 1 Geometries for the "aza" and "carbo" model TSs. Selected distances are reported in $\AA$, Wiberg bond indices calculated from NBO analysis are reported in parenthesis. 


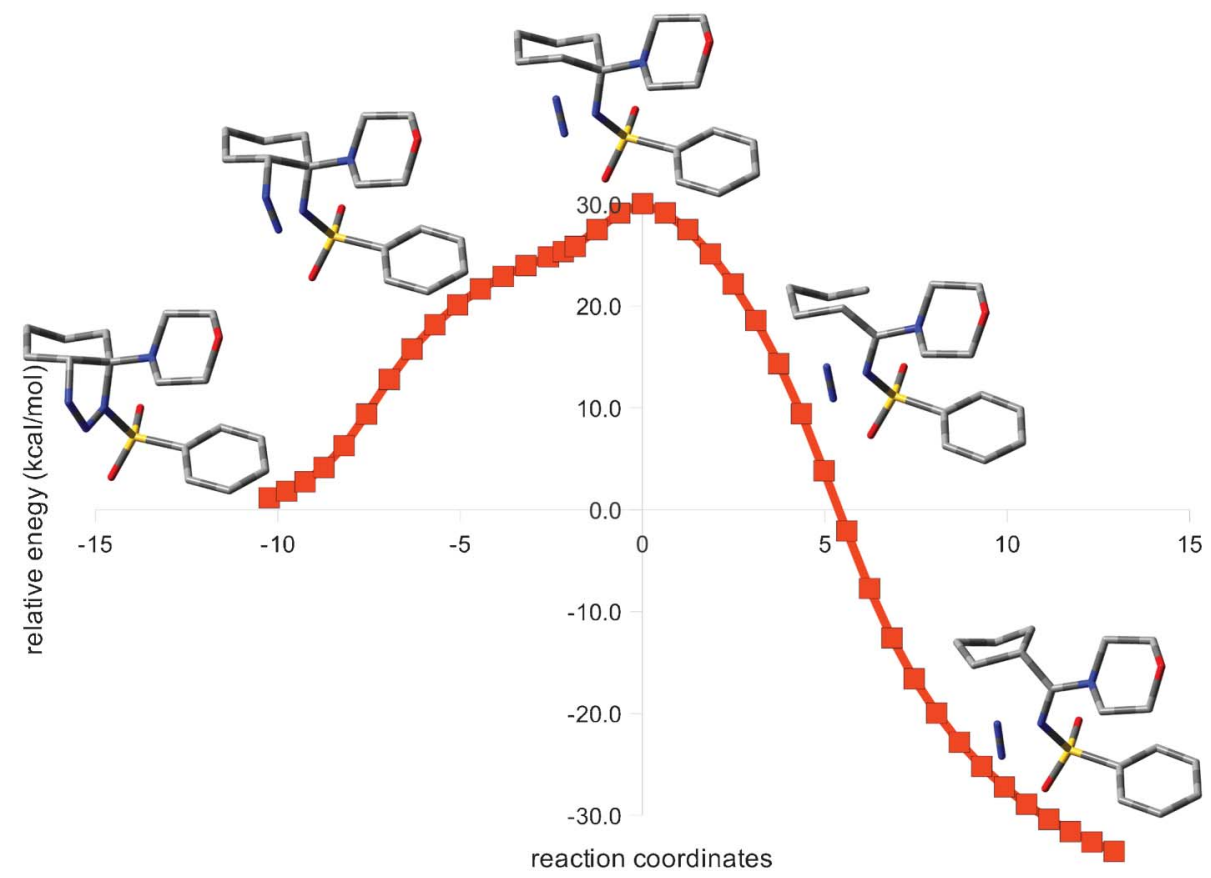

Fig. 2 IRC analysis for the decomposition of triazoline $A_{C}$ ("carbo" model) following path $a$. Geometries for selected points along the reaction energy path are also reported. Energies are calculated relatively to the most stable conformation of triazoline $\mathrm{A}_{\mathrm{C}}$.

by locating the TSs involved in path $b$ for both the "aza" and "carbo" models (TS- $\mathrm{A}_{\mathrm{N}} 2$ and TS- $\mathrm{A}_{\mathrm{C}} 2$, respectively). Activation energies should then favor path $b$ in the former and path $a$ in the latter model.

Both TS- $\mathrm{A}_{\mathrm{N}} 2$ and TS- $\mathrm{A}_{\mathrm{C}} 2$ were obtained from the corresponding triazolines $\mathrm{A} 2$ by lengthening the N1-N2 bond distance and the evaluation of the corresponding activation free energies $\left(\Delta \Delta G^{\dagger}{ }_{\mathrm{b}-\mathrm{a}}=-1.1\right.$ and $2.2 \mathrm{kcal} \mathrm{mol}^{-1}$ for the "aza" and "carbo" models, respectively, accordingly to Table 1) supported our thesis. As expected, a successive IRC analysis (Fig. 3 and Fig. S2, ESI $\%$ ) confirmed that the located TSs directly connect the triazoline reactants with the imino product $\mathrm{C}$, providing further evidence of a concerted decomposition.

To provide a complete description of the reaction, the formation of triazolines $A_{N}$ and $A_{C}$ through the 1,3-dipolar cycloaddition of azide $\mathbf{3}$ with enamines $\mathbf{4}_{\mathbf{N}}$ and $\mathbf{4}_{\mathrm{C}}$ (for "aza" and "carbo" models, respectively) was initially modelled (see Fig. S3,

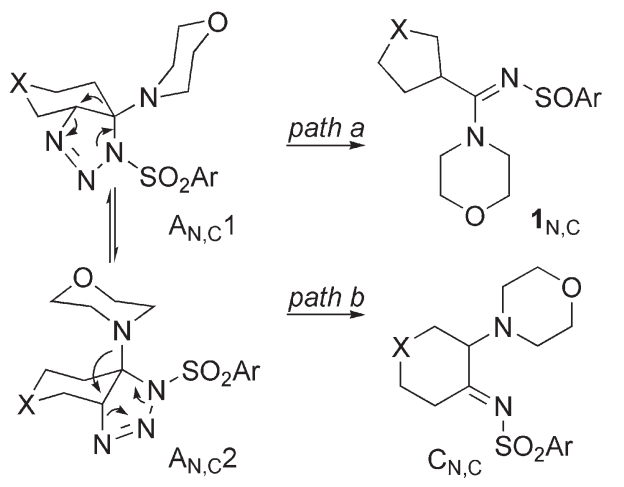

Scheme 5 Proposed concerted reaction mechanism.
ESI:) and the complete reaction profiles are reported in Scheme 6.

For both the "aza" and "carbo" models, the reaction between enamines $\mathbf{3}$ and azide $\mathbf{4}$ occurs with rather low activation free energy barriers, with the reaction of 1-methyl-4-piperidone 3 being less favoured with respect to the carbocyclic analogue (9.1 and $7.3 \mathrm{kcal} \mathrm{mol}^{-1}$, respectively) and leads to the corresponding triazolines with a free energy difference, with respect to isolated reagents, of -21.0 and $-20.2 \mathrm{kcal} \mathrm{mol}^{-1}$ for the "aza" and "carbo" models, respectively, this path being slightly advantagous over the reverse reaction in both cases. The reaction then proceeds through the triazoline decomposition, taking different routes for "carbo" and "aza" models, as described above. In both cases, quite large activation free energies are computed, suggesting that the triazoline might not immediately decompose. In the case of the herein reported compounds $\mathbf{5 a - d}$ and $\mathbf{7 a - c , e}$, this is supported by the experimental observation that nitrogen starts to be released after about 2 min from the addition of the azide, while the reaction reaches completion in about $10 \mathrm{~min}$. In both cases the triazoline decomposition is predicted to be quite exothermic, with free energy differences of -63.5 and $-57.0 \mathrm{kcal}$ $\mathrm{mol}^{-1}$ for the "carbo" and "aza" models. For this latter reaction path, the imino form $\mathrm{C}$, directly obtained from TS- $\mathrm{A}_{\mathrm{N}} 2$, tautomerizes to the most stable enamino forms $5\left(\Delta G_{5-\mathrm{C}}=\right.$ $\left.-1.6 \mathrm{kcal} \mathrm{mol}^{-1}\right)$ and $\mathrm{D}\left(\Delta G_{\mathrm{D}-\mathrm{C}}=-1.2 \mathrm{kcal} \mathrm{mol}^{-1}\right.$, see Scheme 6). While in $\mathrm{Et}_{2} \mathrm{O}$ the enamino tautomer 5 prevails over $\mathrm{D}\left(\Delta G_{5-\mathrm{D}}=-0.4 \mathrm{kcal} \mathrm{mol}^{-1}\right)$, and exactly the opposite is predicted by performing the calculation in chloroform $\left(\Delta G_{\mathrm{D}-5}=\right.$ $-0.4 \mathrm{kcal} \mathrm{mol}^{-1}$ ). These results suggest that both $\mathbf{5}$ and $\mathrm{D}$ enamino forms coexist and their equilibrium can be shifted to one or to the other depending on conditions.

The lower reaction free energy differences obtained for both the path $a$ products (Scheme 6) are not surprising, as the 


\section{solution IRC: path a vs path b "aza" model}

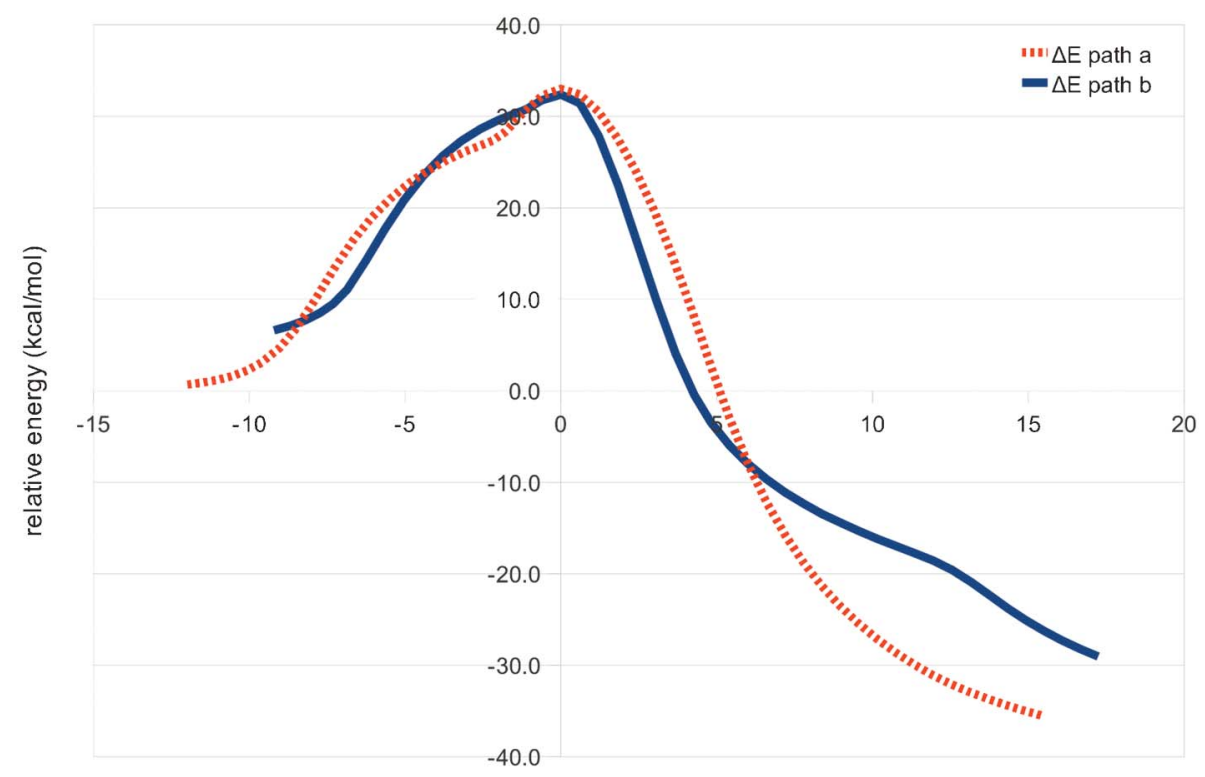

reaction coordinates

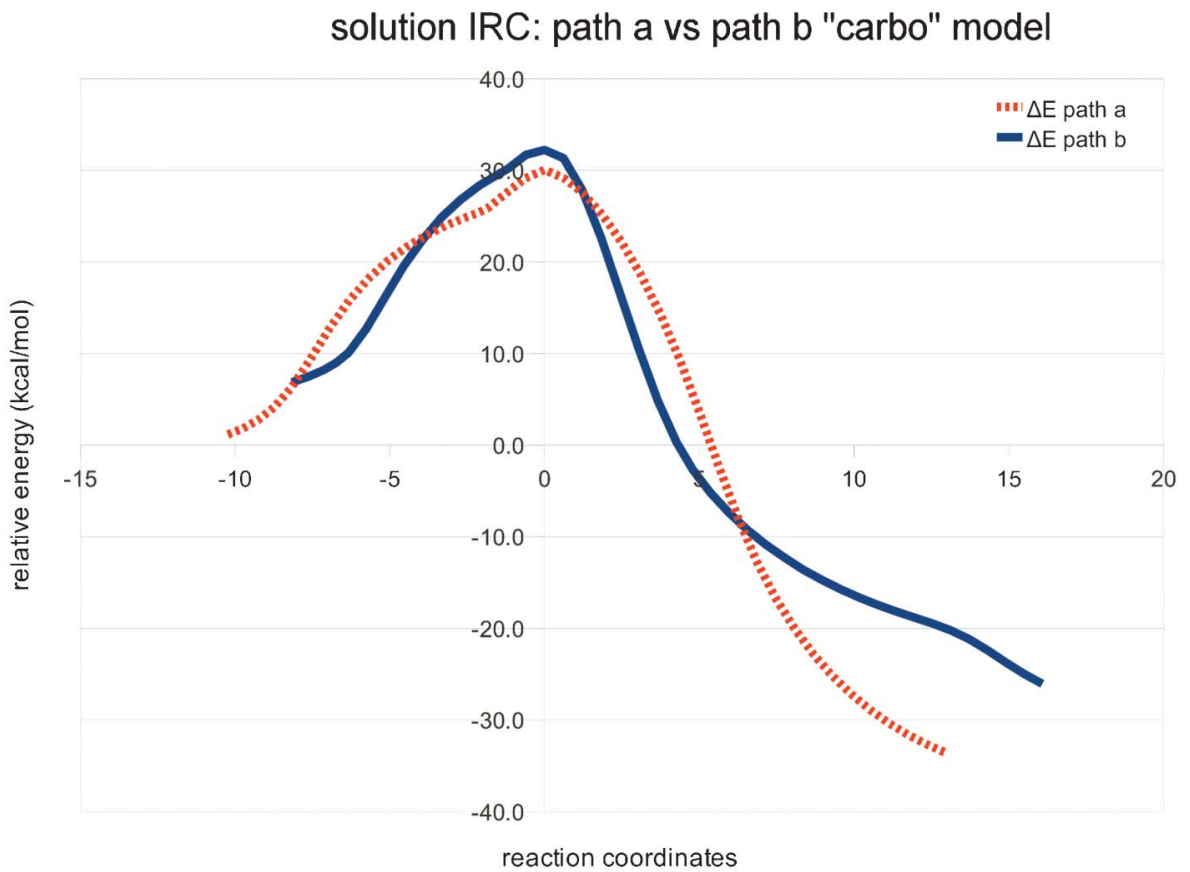

Fig. 3 Intrinsic Reaction Coordinate analysis for the decomposition of triazolines obtained from the enamines of 4-piperidone ("aza" model) or cyclohexanone ("carbo" model).

triazoline decomposition is not reversible and a thermodynamic equilibrium between products is not possible. The outcome might then only be ruled by the energy differences between transition states, making the reaction proceed under exclusive kinetic control.

A further remark should be given on the comparison of activation and reaction free energies for paths $a$ and $b$. While the energy difference between TS-A 1 ("carbo" path a) and TS-A 2 ("carbo" path b; $\Delta G_{\mathrm{b}-\mathrm{a}}=2.2 \mathrm{kcal} \mathrm{mol}^{-1}$ ) fully supports the isolation of 1 as the only product, the difference between TS-A ${ }_{\mathrm{N}} 2$ ("aza" path $b$ ) and TS-A 1 ("aza" path $a ; \Delta G_{\mathrm{b}-\mathrm{a}}=1.1 \mathrm{kcal} \mathrm{mol}^{-1}$ ) appears to be too low to suggest the isolation of $\mathbf{5}$ as the only product. Indeed, according to the Arrhenius equation, the ratio between products $\mathbf{1}_{\mathrm{N}}$ and $\mathrm{C}_{\mathrm{N}}$, predicted from computed activation free energies as $\left[1_{N}\right] /\left[C_{N}\right]=e^{(\Delta G: \mathbf{C}-\Delta G * 1) / R T}$, is $16: 84$. Although we did not expect to exactly reproduce the complex experimental results by a computational method (the mean average errors of some among the most accurate theoretical methods in predicting activation energies for 1,3-dipolar cycloadditions spanned from 1.2 to $3.5 \mathrm{kcal} \mathrm{mol}^{-1} 13$ ), it is true that $16 \%$ of compound $\mathbf{1}_{\mathrm{N}}$ should have been detected by NMR. However, it is also true that for all the reported reactions the principal product precipitated in 

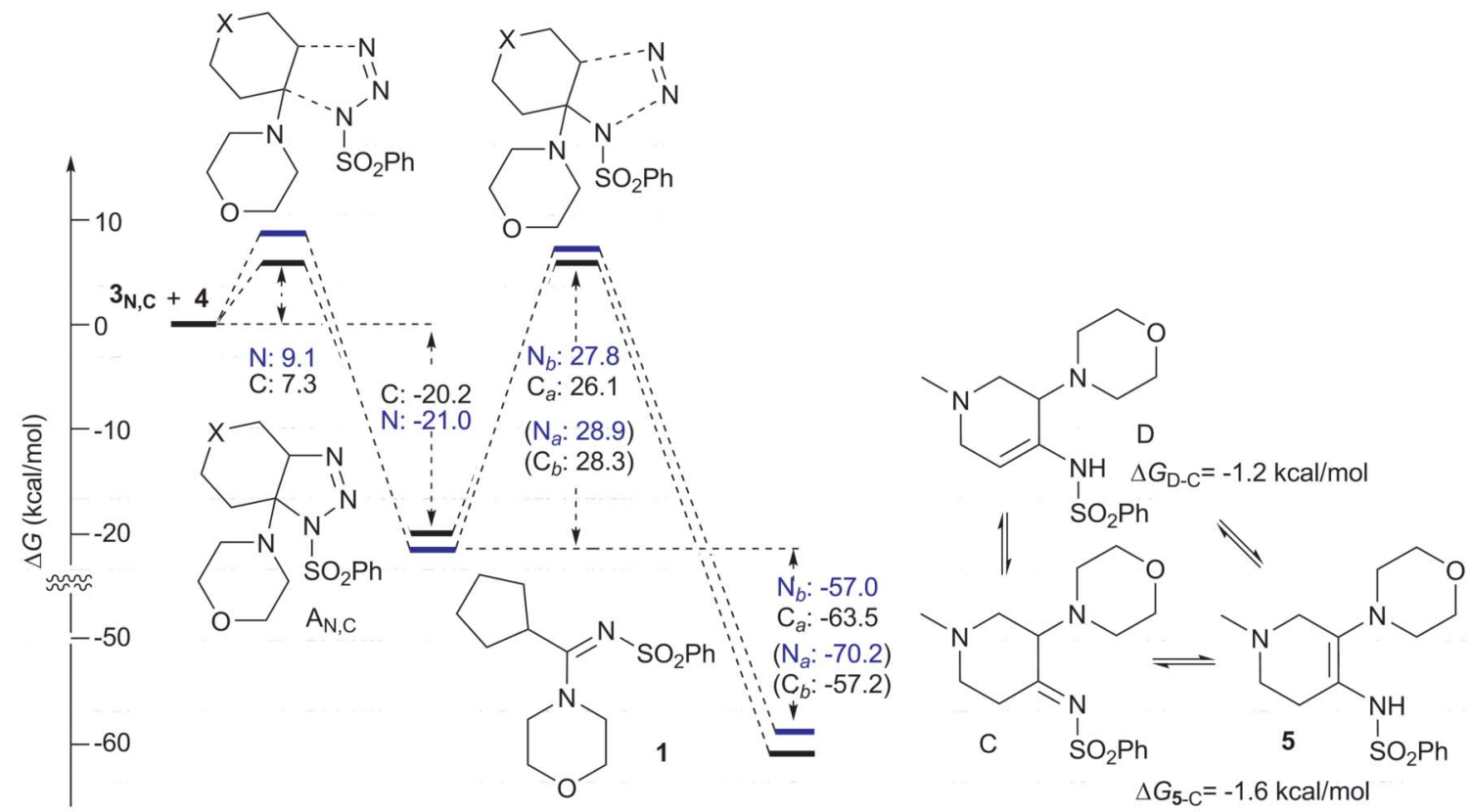

Scheme 6 Complete reaction profiles for "carbo" (black) path $a$ and "aza" (blue) path $b$. Free energy differences are calculated in solution (Et $\left.{ }_{2} \mathrm{O}\right)$ and reported in $\mathrm{kcal} \mathrm{mol}^{-1}$. Free energy differences for the unfavored "carbo" path $b$ and "aza" path $a$ are reported in parenthesis. Thermochemical corrections were obtained from vibrational analyses performed at $298.15 \mathrm{~K}, 1 \mathrm{~atm}$.

the reaction mixture and was isolated in about $80 \%$ yield, while byproducts in the mother liquors were not isolable.

Finally, providing a rationale of the computed activation barriers for "aza" and "carbo" species has not been trivial. Our investigation started from two hypotheses on the role of $\mathrm{N} 5$, that is the stabilization of $\mathrm{TS}-\mathrm{A}_{\mathrm{N}} 2$ or the destabilization of $\mathrm{TS}-\mathrm{A}_{\mathrm{N}} 1$. Nevertheless, the visual inspection of TS geometries for paths $a$ and $b$ of both models evidenced only minor differences, suggesting that the observed outcome should not be ruled by one main reason (such as an evident difference in steric hindrance or the presence of hydrogen bonds at the TS level), but by the combination of different minor effects. For instance, Wiberg bond indices (BIs) ${ }^{14}$ were calculated via $\mathrm{NBO}^{15}$ analysis (see Fig. 1) for TS-A $A_{C, N} 1,2$. Indeed, the difference between BIs $\left(\Delta_{B I}\right)$ at the TS level can be taken as a measure of the synchronicity degree, the lower is $\Delta_{B I}$, the higher is the synchronicity. ${ }^{9 e}$ Such analysis showed that path $b$ TSs were less synchronous than path a TSs, but a higher variation in synchronicity was observed when switching from TS-A $1\left(\Delta_{B I}\right.$ $=0.32)$ to TS-A $A_{N} 2\left(\Delta_{B I}=0.53\right)$ than from TS-A $1\left(\Delta_{B I}=0.33\right)$ to TS-A $2\left(\Delta_{B I}=0.45\right)$. This observation was also supported by the analysis of NBO charges on the leaving $\mathrm{N}_{2}$ group (see Fig. S4, ESI\$), showing a higher cationic character in TS- $\mathrm{A}_{\mathrm{N}} 2$ and TS$\mathrm{A}_{\mathrm{C}} 2\left(\mathrm{~N}_{2}\right.$ charge $=0.219$ and 0.176 , respectively $)$, than in $\mathrm{TS}-\mathrm{A}_{\mathrm{N}} 1$ and TS- $\mathrm{A}_{\mathrm{C}} 1\left(\mathrm{~N}_{2}\right.$ charge $=0.140$ and 0.146 , respectively $)$.

The above data help in defining the chemical-physical variations induced by the replacement of the $\mathrm{C} 5$ with a nitrogen, but a further indication came from an Atom In Molecules $(\mathrm{AIM})^{16}$ wavefunction analysis of $\mathrm{TS}-\mathrm{A}_{\mathrm{N}} 1,-\mathrm{A}_{\mathrm{N}} 2,-\mathrm{A}_{\mathrm{C}} 1$ and $-A_{C} 2$, which by locating bond critical points $(B C P)$ and corresponding bond paths (BP) allows a rigorous identification of those weak interactions that are otherwise difficult to evidence (Fig. 4). Indeed, in recently published studies AIM analysis has been found useful in characterizing TSs leading to competing reaction paths. ${ }^{17}$

As reported in Fig. 4, our analyses show that the replacement of C5 with N5 induces both a destabilization of TS-A 1 with respect to $\mathrm{TS}-\mathrm{A}_{\mathrm{C}} 1$, where $\mathrm{BCP} 1$ defines an additional weak attractive interaction between the $\mathrm{SO}_{2}$ oxygen and the axial $\mathrm{C6}$ hydrogen in the cyclohexane ring, as well as a stabilization of TS$\mathrm{A}_{\mathrm{N}} 2$, where $\mathrm{BCP} 3$ defines an additional weak attractive interaction between the $\mathrm{SO}_{2}$ oxygen and the axial $\mathrm{C} 7$ hydrogen. Other differences can be observed between TS- $\mathrm{A}_{\mathrm{N}} 2$ and TS- $\mathrm{A}_{\mathrm{C}} 2$, that are the presence of a $\mathrm{BCP}$ between $\mathrm{SO}_{2}$ and the $\mathrm{CH}$ next to the morpholine oxygen in TS- $\mathrm{A}_{\mathrm{N}} 2$ (BCP2), not present in TS$\mathrm{A}_{\mathrm{C}} 2$, which is however characterized by an additional BCP between $\mathrm{SO}_{2}$ and the equatorial $\mathrm{C} 7$ hydrogen in the cyclohexane ring. The values of $\rho_{\mathrm{b}}$ (Fig. 4), which are proportional to the strength of the interaction, ${ }^{18}$ at the selected BCPs are in line with values reported in previous work for an analogous weak interaction, ${ }^{17}$ and confirm a clear stabilization effect in TS$A_{N}$ 2. As mentioned above, this analysis is intended to provide a rationale of the observed experimental outcome, but we cannot exclude that other reasons could concur in determining the computed activation barriers.

Seeking for an ultimate proof on the reliability of our theoretical findings, several attempts for locating transition states for a stepwise mechanism were also made by evaluating different levels of theory. However, in every case, TSs from zwitterions $\mathrm{B} 1$ and $\mathrm{B} 2$ to products $\mathbf{1}$ and $\mathrm{C}$ were actually located (TS- $\mathrm{B}_{\mathrm{N}, \mathrm{C}} 1$ and $\mathrm{TS}-\mathrm{B}_{\mathrm{N}, \mathrm{C}} 2$, respectively, see ESI\$) but no TSs connecting triazoline A to zwitterion B were found.

In should be finally considered that the proposed mechanism is only possible if, at the reaction conditions, an equilibrium between conformations A1 and A2 might be established. Moreover, the required energy for the conversion between 

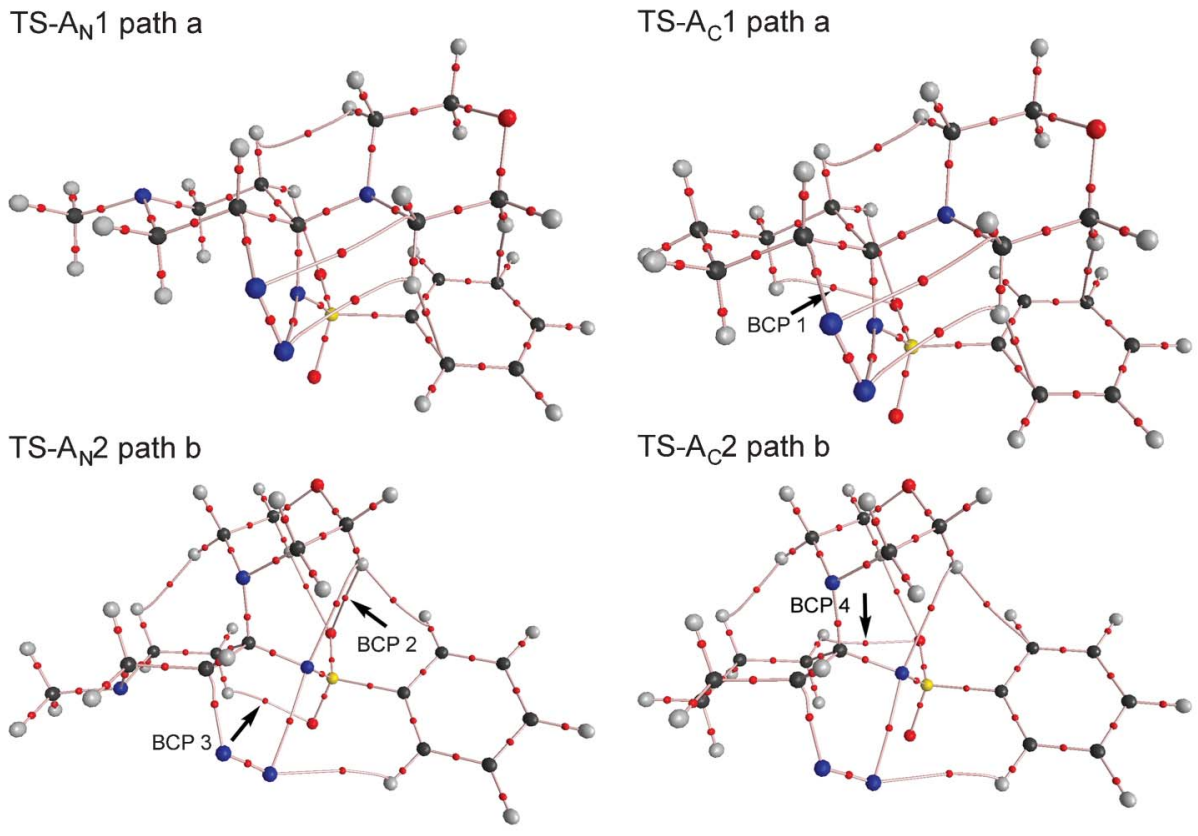

Fig. 4 AIM analyses, molecular graphs and bond critical points (BCP) for TSs of path $a$ (TS-A $\mathrm{A}_{\mathrm{N}} 1$ and TS-A 1 ) and path $b$ (TS-A 2 and TS-A 2 ). Bond paths are denoted by solid lines, BCPs are denoted by small red balls on the bond path. Weak interactions which differentiate "aza" and "carbo" models are evidenced by a black arrow. The values of $\rho_{\mathrm{b}}$ for selected BCP are reported in a.u.: BCP1, 0.0080; BCP2, 0.0076; BCP3, 0.0129; BCP4, 0.0109 .

triazolines A1 and A2 should be lower than the reaction activation energy. In order to prove this, we realized a simple computational model based on the main scaffold of triazoline A, accordingly to Scheme 7. The activation energy for the conformational change between the most stable chair conformation and the boat intermediate was then calculated by locating the corresponding TSs $\left(\Delta G^{*}=6.6\right.$ and $6.9 \mathrm{kcal} \mathrm{mol}^{-1}$ for the chair 1 to boat transition and 7.5 and $5.0 \mathrm{kcal} \mathrm{mol}^{-1}$ for the boat to chair 2 transition in the "aza" and "carbo" models, respectively), and was far below the activation energy required for the reaction to proceed via either path $a$ or $b\left(\Delta G^{\ddagger}=28.9\right.$ and $27.8 \mathrm{kcal} \mathrm{mol}^{-1}$, respectively, for the "aza" model), confirming that an equilibrium between the two triazoline conformations is possible in the reaction conditions.

\section{Conclusion}

A series of new azacycloalkene monosulfonyl diamines $\mathbf{5}$ and $\mathbf{7}$ has been efficiently prepared trough a click-chemistry approach affording the desired products in good yields.

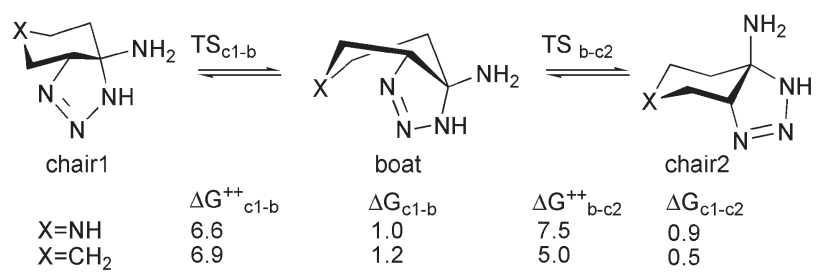

Scheme 7 Chair-twisted boat-reversed chair equilibrium. Activation and reaction free energy differences are calculated in solution and reported in $\mathrm{kcal} \mathrm{mol}^{-1}$.
The key reaction step, consisting of the decomposition and rearrangement of the 1,2,3-triazoline intermediate, has been modeled and compared to the parent carbocyclic derivative, which only leads to the amidine product through the ring contraction mechanism. Contrarily to what is expected, the triazoline decomposition occurs in both cases in a concerted manner, directly leading to the final products. The reaction is predicted to be under kinetic control and the selectivity toward the diamino derivatives can be due to stabilising weak interactions at the TS level, as evidenced by AIM analyses.

\section{Experimental}

\section{Theoretical calculations}

Reactants $\mathbf{3}_{\mathrm{N}}, \mathbf{3}_{\mathrm{C}}, \mathbf{4}, \mathrm{A}_{\mathrm{N}} 1, \mathrm{~A}_{\mathrm{N}} 2, \mathrm{~A}_{\mathrm{C}} 1, \mathrm{~A}_{\mathrm{C}} 2$, zwitterions $\mathrm{B}_{\mathrm{N}} 1, \mathrm{~B}_{\mathrm{N}} 2$, $\mathrm{B}_{\mathrm{C}} 1, \mathrm{~B}_{\mathrm{C}} 2$ and products $\mathbf{1}_{\mathrm{N}}, \mathbf{1}_{\mathrm{C}}, \mathrm{C}_{\mathrm{N}}, \mathrm{C}_{\mathrm{C}}, \mathbf{5}_{\mathrm{N}}$ and $\mathrm{D}_{\mathrm{N}}$ were obtained from a conformational search performed in vacuum at the molecular mechanic level using the MMFF94x force field implemented in MOE, ${ }^{19}$ and subsequently optimized at the mPW1B95/6-31+G(d,p) level of theory. ${ }^{10}$ Transition states TS$3+4_{N, C}, T S-A_{N} 1, A_{N} 2, A_{C} 1$ and $-A_{C} 2$ were then constructed and fully optimized at the same level of theory. Vibrational frequencies were computed at the same level of theory in order to define optimized geometries as minima (no imaginary frequencies) or TSs (a unique imaginary frequency corresponding to the vibrational stretching of the forming/breaking bonds) and to calculate zero-point and thermochemical corrections to electronic energies (1 atm, 298.15 K, unscaled frequencies). In order to verify that no other minima or TSs were present over the reaction path, IRC analyses ${ }^{12}$ were performed at the $\mathrm{mPW} 1 \mathrm{~B} 95 /$ $6-31+G(d, p)$ level starting from TS- $A_{N} 1, A_{N} 2, A_{C} 1$ and $-A_{C} 2$, and requesting the localization of 30 points along each direction 
of the reaction path (forward and reverse) with a step size of 0.2 $\mathrm{amu}^{1 / 2}$ bohr. All calculations were performed in both the gas phase and in solution, using the CPCM solvent model for diethyl ether (and chloroform, for tautomeric forms $\mathrm{C}_{\mathrm{N}}, 5_{\mathrm{N}}$ and $\mathrm{D}_{\mathrm{N}}$ ), ${ }^{11}$ as implemented in the Gaussian09 software package. ${ }^{20}$ AIM analyses ${ }^{16,18}$ were performed on the wavefunctions obtained from the CPCM-mPW1B95/6-31+G(d,p) optimized TS-A $1, A_{N} 2, A_{C} 1$ and $-\mathrm{A}_{\mathrm{C}} 2$ geometries using the AIM2000 software. ${ }^{21}$

\section{Chemistry}

Mps were determined by a Büchi 510 (capillary) apparatus. IR was performed with Perkin-Elmer FT-IR 'Spectrum One' (KBr), NMR spectra, performed at $25{ }^{\circ} \mathrm{C}$, were obtained with Bruker Advance 300, Bruker Advance 500 and Varian Gemini 200 spectrometers in $\mathrm{CDCl}_{3}$. Low-resolution MS spectra were recorded with a Thermo-Finnigan LCQ ADVANTAGE AP electrospray/ion trap equipped instrument using a syringe pump device for the direct injection of sample solutions.

The synthesis of enamine $3 \mathbf{a}^{22}$ and $\mathbf{6}^{23}$ was previously described.

\section{Synthesis of tosylamides 5 and 7}

General Procedure: Enamine 3a and 6 (3 mmol) were dissolved in $20 \mathrm{~mL}$ of diethyl ether. The solution was cooled with a cold bath $\left(5-10{ }^{\circ} \mathrm{C}\right)$ and azide $4 \mathbf{a}-\mathbf{e}(3 \mathrm{mmol})$ was added. A plentiful extrication of gas was observed after $2 \mathrm{~min}$. from the addition of azide and the reaction was ended in $10 \mathrm{~min}$. (TLC ethyl acetatecyclohexane $1: 1)$. The abundant precipitate was filtered and dried in vacuum.

4-Methyl- $N$-(1-methyl-5-morpholino-1,2,3,6-tetrahydro-pyridin-4yl)-benzensulfonamide (5a)

Yield 78\%; white solid; mp $109-110{ }^{\circ} \mathrm{C}$ (from $\mathrm{Et}_{2} \mathrm{O}$ ). $v_{\max } / \mathrm{cm}^{-1}$ 3435 and $3207(\mathrm{NH}) . \delta_{\mathrm{H}}\left(200 \mathrm{MHz} ; \mathrm{CDCl}_{3}, \mathrm{Me}_{4} \mathrm{Si}\right):=2.24-2.31$ (m, 5H, 2 $\left.\mathrm{CH}_{2}+\mathrm{NH}\right), 2.32\left(\mathrm{~s}, 3 \mathrm{H}, \mathrm{CH}_{3}-\mathrm{N}\right), 2.39$ (s, 3H, $\left.\mathrm{CH}_{3} \mathrm{Ph}\right)$, 2.45-2.49 (m, 4H, $\left.\mathrm{CH}_{2}-\mathrm{N}\right), 2.82-2.86\left(\mathrm{~m}, 2 \mathrm{H}, \mathrm{CH}_{2}-2\right), 5.62-5.68$ (m, 1H, CH), 7.27 (d, J = 7.0 Hz, 2H, Ar-H), $7.70(\mathrm{~d}, 7.0 \mathrm{~Hz}, 2 \mathrm{H}$, $\mathrm{Ar}-\mathrm{H})$ ppm. $\delta_{\mathrm{C}}\left(50 \mathrm{MHz} ; \mathrm{CDCl}_{3}\right)=21.7\left(\mathrm{CH}_{3}\right), 26.2\left(\mathrm{CH}_{2}\right)$, $46.0\left(\mathrm{CH}_{3}\right), 49.9\left(\mathrm{CH}_{2}\right), 50.4\left(\mathrm{CH}_{2}\right), 51.8\left(\mathrm{CH}_{2}\right), 67.4\left(\mathrm{CH}_{2}\right), 126.0$ (C), 127.1(CH), 129.0(C), 129.9(C), 137.4(C), 143(C). $\mathrm{m} / \mathrm{z} 352$ $\left(\mathrm{M}^{+}\right)$. Found: $\mathrm{C}, 57.9 ; \mathrm{H}, 7.3 ; \mathrm{N} 11.8$ calcd. for $\mathrm{C}_{17} \mathrm{H}_{25} \mathrm{~N}_{3} \mathrm{O}_{3} \mathrm{~S} \mathrm{C}$, 58.1; H,7.2; N, 11.9.

\section{4-Nitro- $N$-(1-methyl-5-morpholino-1,2,3,6-tetrahydro-pyridin-4- yl)-benzensolfonamide (5b)}

Yield 85\%; pale yellow solid; mp 103-104 ${ }^{\circ} \mathrm{C}$ (from $i \operatorname{Pr}_{2} \mathrm{O}$ ). $v_{\max } /$ $\mathrm{cm}^{-1} 3436$ and $3283(\mathrm{NH}) . \delta_{\mathrm{H}}\left(200 \mathrm{MHz} ; \mathrm{CDCl}_{3}\right)=2.24(\mathrm{~s}, 3 \mathrm{H}$, $\left.\mathrm{CH}_{3}-\mathrm{N}\right), 2.25-2.38\left(\mathrm{~m}, 6 \mathrm{H}, 3 \mathrm{CH}_{2-5+\mathrm{D}}\right), 2.40-3.08\left(\mathrm{~m}, 3 \mathrm{H}, \mathrm{CH}_{2^{-}}\right.$ $\left.2-5+\mathrm{CH}_{2}-2_{\mathbf{D}}+\mathrm{CH}_{\mathbf{D}}\right), 3.58-3.82\left(\mathrm{~m}, 4 \mathrm{H}, 2 \mathrm{CH}_{2} \mathrm{O}\right), 5.76-5.81(\mathrm{~m}$, $\left.1 \mathrm{H}, \mathrm{CH}-5_{\mathrm{D}}\right), 8.06$ (d, $\left.J=7.0 \mathrm{~Hz}, 2 \mathrm{H}, \mathrm{Ar}-\mathrm{H}\right), 8.33(\mathrm{~d}, J=7.0 \mathrm{~Hz}$, $2 \mathrm{H}, \mathrm{Ar}-\mathrm{H})$ ppm. $\delta_{\mathrm{H}}(200 \mathrm{MHz} ; \mathrm{DMSO})=2.11\left(\mathrm{~s}, \mathrm{CH}_{3}-\mathrm{N}\right)$, 2.10-2.38 (m, 5H, 2 $\left.\mathrm{CH}_{2} \mathrm{~N}+\mathrm{CH}-3\right), 3.02-3.09$ (m, 1H, CH-3), $3.25-3.63\left(\mathrm{~m}, 8 \mathrm{H}, 2 \mathrm{CH}_{2}-\mathrm{O}+2 \mathrm{CH}_{2}-\mathrm{N}\right), 8.06(\mathrm{~d}, J=7.0 \mathrm{~Hz}, 2 \mathrm{H}$, $\mathrm{Ar}-\mathrm{H}), 8.33$ (d, $J=7.0 \mathrm{~Hz}, 2 \mathrm{H}, \mathrm{Ar}-\mathrm{H}), 8.68$ (sb, 1H, NH) ppm. $\delta_{\mathrm{C}}\left(50 \mathrm{MHz} ; \mathrm{CDCl}_{3}, \mathrm{Me}_{4} \mathrm{Si}\right)=26.0\left(\mathrm{CH}_{2-5}\right), 45.6\left(\mathrm{CH}_{3-\mathrm{D}}\right), 45.7$ $\left(\mathrm{CH}_{3-5}\right), 49.1\left(\mathrm{CH}_{2-5}\right), 50.0\left(\mathrm{CH}_{2-5}\right), 50.5\left(\mathrm{CH}_{2-\mathrm{D}}\right), 51.6\left(\mathrm{CH}_{2-5}\right)$ $56.4\left(\mathrm{CH}_{2-\mathbf{D}}\right), 57.6\left(\mathrm{CH}_{2-\mathbf{D}}\right), 61.1\left(\mathrm{CH}_{-\mathbf{D}}\right), 67.3\left(\mathrm{CH}_{2-5+\mathbf{D}}\right), 110.7$
$\left(\mathrm{CH}_{-\mathbf{D}}\right), 124.5\left(\mathrm{CH}_{-5+\mathrm{D}}\right), 125.1\left(\mathrm{C}_{-5}\right), 128.4\left(\mathrm{CH}_{-5+\mathrm{D}}\right), 129.2$ (C-D), 129.9 (C-5), $146.4\left(\mathrm{C}_{-5+\mathbf{D}}\right), 150.4\left(\mathrm{C}_{-5+\mathrm{D}}\right) . \mathrm{m} / \mathrm{z} 383\left(\mathrm{M}^{+}\right)$. Found: C, 50.0; H, 5.9; N 14.5 calcd. for $\mathrm{C}_{16} \mathrm{H}_{22} \mathrm{~N}_{4} \mathrm{O}_{5} \mathrm{~S}$ C, 50.2; $\mathrm{H}, 5.8 ; \mathrm{N}, 14.6$

\section{N-(1-Methyl-5-morpholino-1,2,5,6-tetrahydro-pyridin-4-yl)-2- phenylethenesolfonamide (5c)}

Yield 83\%; white solid; mp 108-109 ${ }^{\circ} \mathrm{C}$ (from $\mathrm{Et}_{2} \mathrm{O}$ ). $v_{\max } / \mathrm{cm}^{-1}$ $3238(\mathrm{NH}) . \delta_{\mathrm{H}}\left(200 \mathrm{MHz} ; \mathrm{CDCl}_{3}, \mathrm{Me}_{4} \mathrm{Si}\right)=2.34\left(\mathrm{~s}, 3 \mathrm{H}, \mathrm{CH}_{3} \mathrm{~N}\right)$, $2.24-2.78\left(\mathrm{~m}, 6 \mathrm{H}, 3 \mathrm{CH}_{2} \mathrm{~N}\right), 2.82-3.05\left(\mathrm{~m}, 2 \mathrm{H}, \mathrm{CH}_{2} \mathrm{~N}\right), 3.24-3.38$ (m, 1H, CH-3), 3.62-3.78 (m, 4H, $\left.\mathrm{CH}_{2} \mathrm{O}\right), 5.74-5.79(\mathrm{~m}, 1 \mathrm{H}$, $\mathrm{CH}-5), 7.82\left(\mathrm{~d}, J=15.63 \mathrm{~Hz}, 1 \mathrm{H}, \mathrm{CHSO}_{2}\right), 7.38-7.50(\mathrm{~m}, 4 \mathrm{H}$, $\mathrm{Ar}-\mathrm{H}), 7.53(\mathrm{~d}, J=15.63 \mathrm{~Hz}, 1 \mathrm{H}, \mathrm{CHPh}) \mathrm{ppm} . \delta_{\mathrm{C}}(50 \mathrm{MHz}$; $\left.\mathrm{CDCl}_{3}, \mathrm{Me}_{4} \mathrm{Si}\right)=45.5\left(\mathrm{CH}_{3}\right), 49.1\left(\mathrm{CH}_{2}\right), 50.2\left(\mathrm{CH}_{2}\right), 53.6$ $\left(\mathrm{CH}_{2}\right), 61.1(\mathrm{CH}), 63.4\left(\mathrm{CH}_{2}\right), 67.5\left(\mathrm{CH}_{2}\right), 108.4(\mathrm{CH}), 124.0$ $(\mathrm{CH}), 128.5(\mathrm{CH}), 129.3(\mathrm{CH}), 129.6(\mathrm{C}), 123.7(\mathrm{C}), 131.1(\mathrm{CH})$, 132.7 (C), 142.6(CH). m/z $364\left(\mathrm{M}^{+}\right)$. Found: C, 59.2; N, 7.0; N, 11.3 calcd. for $\mathrm{C}_{18} \mathrm{H}_{25} \mathrm{~N}_{3} \mathrm{O}_{3} \mathrm{~S} \mathrm{C}, 59.5 ; \mathrm{H}, 6.9 ; \mathrm{N}, 11.6$.

\section{2-Nitro- $N$-(1-methyl-5-morpholino-1,2,3,6-tetrahydro-pyridin-4- yl)-benzensolfonamide (5d)}

Yield 87\%; pale yellow solid; mp 95-97 ${ }^{\circ} \mathrm{C}$ (from $\mathrm{Et}_{2} \mathrm{O}$ ). $v_{\max } /$ $\mathrm{cm}^{-1} 3396$ and $3215(\mathrm{NH}) . \delta_{\mathrm{H}}\left(200 \mathrm{MHz} ; \mathrm{CDCl}_{3}, \mathrm{Me}_{4} \mathrm{Si}\right)=2.47$ (s, 3H, $\mathrm{CH}_{3} \mathrm{~N}_{\mathrm{D}+6}$ ), 2.33-2.65 (m, 6H, 3C $\left.\mathrm{CH}_{2} \mathrm{~N}_{5+6}\right), 2.72-3.10$ (m, $\left.3 \mathrm{H}, \mathrm{CH}_{2}-2-5+\mathrm{CH}_{2}-2_{\mathrm{D}}+\mathrm{CH}_{6}\right), 3.65-3.80\left(\mathrm{~m}, 4 \mathrm{H}, 2 \mathrm{CH}_{2} \mathrm{O}\right)$, 5.89-5.96 (m, 1H, CH-5 $), 7.63-8.25(\mathrm{~m}, 4 \mathrm{H}, \mathrm{ArH}) \mathrm{ppm} . \delta_{\mathrm{C}}$ $\left(50 \mathrm{MHz} ; \mathrm{CDCl}_{3}\right)=26.3\left(\mathrm{CH}_{2-5}\right), 45.6\left(\mathrm{CH}_{3-\mathrm{D}}\right), 45.5\left(\mathrm{CH}_{3-5}\right)$, $49.1\left(\mathrm{CH}_{2-5}\right), 50.2\left(\mathrm{CH}_{2-5}\right), 50.3\left(\mathrm{CH}_{2-\mathrm{D}}\right), 51.7\left(\mathrm{CH}_{2-5}\right), 56.0$ $\left(\mathrm{CH}_{2-\mathrm{D}}\right), 57.6\left(\mathrm{CH}_{2-\mathrm{D}}\right), 61.3\left(\mathrm{CH}_{-\mathbf{D}}\right), 67.0\left(\mathrm{CH}_{2-5}\right), 67.3\left(\mathrm{CH}_{2-\mathrm{D}}\right)$, $112.2\left(\mathrm{CH}_{-\mathbf{D}}\right), 125.2\left(\mathrm{CH}_{-5+\mathbf{D}}\right), 129.4\left(\mathrm{C}_{-5}\right), 129.9,131.1,131.9$, 132.7, 133.4, $134.4\left(\mathrm{CH}_{-5+D}\right), 133.0\left(\mathrm{C}_{-\mathbf{D}}\right), 129.9\left(\mathrm{C}_{-5}\right), 136.4$ $\left(\mathrm{C}_{-5+\mathrm{D}}\right), 148.3\left(\mathrm{C}_{-5+\mathrm{D}}\right) . \mathrm{m} / \mathrm{z} 383\left(\mathrm{M}^{+}\right)$. Found: C, 50.1; H, 6.0; $\mathrm{N} 14.4$ calcd. for $\mathrm{C}_{16} \mathrm{H}_{22} \mathrm{~N}_{4} \mathrm{O}_{5} \mathrm{~S} \mathrm{C}, 50.2 ; \mathrm{H}, 5.8 ; \mathrm{N}, 14.6$

\section{4-Methyl- $N$-(8-methyl-2-morpholino-8-aza-bicyclo[3,2,1]oct-2-en- 3-yl)benzensulfonamide (7a)}

Yield 88\%; white solid; mp 85-86 ${ }^{\circ} \mathrm{C}$ (from $\mathrm{Et}_{2} \mathrm{O}$ ). $v_{\max } / \mathrm{cm}^{-1}$ $3435(\mathrm{NH}) . \delta_{\mathrm{H}}\left(200 \mathrm{MHz} ; \mathrm{CDCl}_{3}, \mathrm{Me}_{4} \mathrm{Si}\right)=1.75-2.79(\mathrm{~m}, 10 \mathrm{H}$, $\left.5 \mathrm{CH}_{2}\right), 2.27\left(\mathrm{~s}, 3 \mathrm{H}, \mathrm{CH}_{3} \mathrm{~N}\right), 2.47\left(\mathrm{~s}, 3 \mathrm{H}, \mathrm{CH}_{3} \mathrm{Ph}\right), 3.24-3.55(\mathrm{~m}$, $2 \mathrm{H}, 2 \mathrm{CHN}), 3.61-3.71\left(\mathrm{~m}, 4 \mathrm{H}, 2 \mathrm{CH}_{2} \mathrm{O}\right), 7.28-732$ (m, 2H, ArH), 7.69-7.87 (m, 2H, ArH) ppm. ${ }^{13} \mathrm{C}$ NMR of mixture of imino $\mathrm{C}$ and enamino 7 forms (see discussion) $\delta_{\mathrm{C}}\left(50 \mathrm{MHz} ; \mathrm{CDCl}_{3}\right.$, $\left.\mathrm{Me}_{4} \mathrm{Si}\right)=21.6\left(\mathrm{CH}_{3-\mathrm{i}+\mathrm{e}}\right), 24.8\left(\mathrm{CH}_{2 \mathbf{i}}\right), 27.6\left(\mathrm{CH}_{2 \mathrm{i}}\right), 30.2\left(\mathrm{CH}_{2 \mathrm{e}}\right)$, $30.7\left(\mathrm{CH}_{2 \mathbf{e}}\right), 35.3\left(\mathrm{CH}_{3} \mathrm{~N}_{-\mathbf{i}+\mathbf{e}}\right), 35.2\left(\mathrm{CH}_{2 \mathbf{e}}\right), 38.0\left(\mathrm{CH}_{\mathbf{i}}\right), 50.5$ $\left(\mathrm{CH}_{2} \mathrm{~N}_{\mathbf{i}}\right), 51.1\left(\mathrm{CH}_{2} \mathrm{~N}_{\mathbf{e}}\right), 55.5\left(\mathrm{CH}_{\mathbf{i}}\right), 57.0\left(\mathrm{CH}_{\mathbf{e}}\right), 62.8\left(\mathrm{CH}_{\mathbf{e}}\right), 64.3$ $\left(\mathrm{CH}_{\mathbf{i}}\right), 67.2\left(\mathrm{CH}_{2} \mathrm{O}_{\mathbf{i}}\right), 67.3\left(\mathrm{CH}_{2} \mathrm{O}_{\mathbf{e}}\right), 123.9\left(\mathrm{C}_{\mathbf{e}}\right), 127.0\left(\mathrm{CH}_{\mathbf{e}}\right)$, $127.2\left(\mathrm{CH}_{\mathbf{i}}\right), 129.5\left(\mathrm{CH}_{\mathbf{e}}\right), 129.7\left(\mathrm{CH}_{\mathbf{i}}\right), 134.0\left(\mathrm{C}_{\mathbf{e}}\right), 137.5\left(\mathrm{C}_{-\mathrm{e}+\mathrm{i}}\right)$, $143.5\left(\mathrm{C}_{\mathbf{e}}\right), 143.9\left(\mathrm{C}_{\mathbf{i}}\right), 187.2\left(\mathrm{C}=\mathrm{N}_{\mathbf{i}}\right) . m z$ 378( $\left.\mathrm{M}^{+}\right)$. Found: $\mathrm{C}$, $60.3 ; \mathrm{H}, 7.5 ; \mathrm{N}, 11.0$ calcd. for $\mathrm{C}_{19} \mathrm{H}_{27} \mathrm{~N}_{3} \mathrm{O}_{3} \mathrm{~S} \mathrm{C}, 60.4 ; \mathrm{H}, 7.2 ; \mathrm{N}$, 11.1 .

\section{$N$-(8-Methyl-2-morpholino-8-aza-bicyclo[3,2,1]oct-2-en-3-yl)-4- nitrobenzensulfonamide $(7 \mathrm{~b})$}

Yield 85\%; pale yellow solid; mp $130-131{ }^{\circ} \mathrm{C}$ (from $\mathrm{Et}_{2} \mathrm{O}$ ). $v_{\max } /$ $\mathrm{cm}^{-1} 3436.0(\mathrm{NH}) . \delta_{\mathrm{H}}\left(200 \mathrm{MHz} ; \mathrm{CDCl}_{3}, \mathrm{Me}_{4} \mathrm{Si}\right)=1.75-2.82$ $(\mathrm{m}, 10 \mathrm{H}, 5 \mathrm{CH} 2), 2.23\left(\mathrm{~s}, 3 \mathrm{H}, \mathrm{CH}_{3} \mathrm{~N}\right), 3.22-3.79(\mathrm{~m}, 6 \mathrm{H}, 2 \mathrm{CH}+$ $2 \mathrm{CH} 2 \mathrm{O}), 8.02-8.43(\mathrm{~m}, 4 \mathrm{H}, \mathrm{ArH}) \mathrm{ppm} . \delta_{\mathrm{C}}\left(75 \mathrm{MHz}^{-\mathrm{CDCl}_{3}}\right.$, 
$\left.\mathrm{Me}_{4} \mathrm{Si}\right)=30.0\left(\mathrm{CH}_{2}\right), 30.9\left(\mathrm{CH}_{2}\right), 35.0\left(\mathrm{CH}_{2}\right), 35.6(\mathrm{CH} 3), 50.6$ $\left(\mathrm{CH}_{2}\right), 55.8(\mathrm{CH}), 57.2(\mathrm{CH}), 67.2\left(\mathrm{CH}_{2}\right), 122,8(\mathrm{C}), 124.4(\mathrm{CH})$, $128.4(\mathrm{CH}), 134.8(\mathrm{C}), 146.5(\mathrm{C}), 150.4(\mathrm{C}) . \mathrm{m} / \mathrm{z} 409\left(\mathrm{M}^{+}\right)$. Found: C, 52.7; H, 6.1; N, 13.6 calcd. for $\mathrm{C}_{18} \mathrm{H}_{24} \mathrm{~N}_{4} \mathrm{O}_{5} \mathrm{~S}$ C, 52.9; H, 5.9; N, 13.7 .

\section{N-(8-Methyl-2-morpholino-8-aza-bicyclo[3,2,1]oct-2-en-3-yl)- phenylethenesulfonamide $(7 \mathrm{c})$}

Yield 78\%; white solid; mp 98-99 ${ }^{\circ} \mathrm{C}$ (from $\mathrm{Et}_{2} \mathrm{O}$ ). $v_{\max } / \mathrm{cm}^{-1}$ $3435.4(\mathrm{NH}) . \delta_{\mathrm{H}}\left(200 \mathrm{MHz} ; \mathrm{CDCl}_{3}, \mathrm{Me}_{4} \mathrm{Si}\right)=2.16-2.25(\mathrm{~m}, 2 \mathrm{H}$, $\left.\mathrm{CH}_{2}\right), 2.44\left(\mathrm{~s}, 3 \mathrm{H}, \mathrm{CH}_{3} \mathrm{~N}\right), 2.61-2.65\left(\mathrm{~m}, 4 \mathrm{H}, 2 \mathrm{CH}_{2} \mathrm{~N}\right), 3.01-3.10$ $\left(\mathrm{m}, 2 \mathrm{H}, \mathrm{CH}_{2}\right), 3.45-3.68(\mathrm{~m}, 2 \mathrm{H}, 2 \mathrm{CH}), 3.68-3.73(\mathrm{~m}, 4 \mathrm{H}$, $\left.2 \mathrm{CH}_{2} \mathrm{O}\right), 3.80-3.84\left(\mathrm{~m}, 2 \mathrm{H}, \mathrm{CH}_{2}\right), 6.96(\mathrm{~d}, J=15.1 \mathrm{~Hz}, 1 \mathrm{H}$, $\mathrm{CHPh}), 7.38-7.54(\mathrm{~m}, 6 \mathrm{H}, \mathrm{CH}+\mathrm{ArH}) \mathrm{ppm} . \delta_{\mathrm{C}}(50 \mathrm{MHz}$; $\left.\mathrm{CDCl}_{3}, \mathrm{Me}_{4} \mathrm{Si}\right)=29.6\left(\mathrm{CH}_{2}\right), 31.1\left(\mathrm{CH}_{2}\right), 34.6\left(\mathrm{CH}_{2}\right), 35.8$ $\left(\mathrm{CH}_{3}\right), 44.9\left(\mathrm{CH}_{2}\right), 56.4(\mathrm{CH}), 57.9(\mathrm{CH}), 67.2(\mathrm{CH}), 123.6(\mathrm{C})$, $126.6(\mathrm{CH}), 128(\mathrm{CH}), 129.4(\mathrm{CH}), 131.2(\mathrm{CH}), 132.6(\mathrm{C}), 141.7$ (CH). $\mathrm{m} / \mathrm{z}$ 390( $\left(\mathrm{M}^{+}\right)$. Found: C, 61.5; H, 7.1; N, 10.6 calcd. for $\mathrm{C}_{20} \mathrm{H}_{27} \mathrm{~N}_{3} \mathrm{O}_{3} \mathrm{~S} \mathrm{C}, 61.7 ; \mathrm{H}, 67.0$, N, 10.79.

\section{$\mathrm{N}$-(8-Methyl-2-morpholino-8-aza-bicyclo[3,2,1]oct-2-en-3-yl)- (phenyl)-methansulfonamide (7d)}

Yield 80\%; white solid; mp 95-97 ${ }^{\circ} \mathrm{C}$ (from $\mathrm{Et}_{2} \mathrm{O}$ ). $v_{\max } / \mathrm{cm}^{-1}$ $3437.5(\mathrm{NH}) . \delta_{\mathrm{H}}\left(500 \mathrm{MHz} ; \mathrm{CDCl}_{3}, \mathrm{Me}_{4} \mathrm{Si}\right)=1.48-1.57(\mathrm{~m}, 1 \mathrm{H}$, H-6), 1.79-1.87 (m, 1H, H-7), 1.96-2.04 (m, 1H, H-4), 2.13-2.25 $(\mathrm{m}, 2 \mathrm{H}, \mathrm{H}-6$ and $\mathrm{H}-7), 2.37\left(\mathrm{~s}, 3 \mathrm{H}, \mathrm{CH}_{3} \mathrm{~N}\right), 2.52-2.60(\mathrm{~m}, 4 \mathrm{H}$, $2 \mathrm{CH}_{2} \mathrm{~N}$ ), 2.72-2.80 (m, 1H, H-4), 3.31-3.37 (m, 1H, H-5), 3.47$3.51(\mathrm{~m}, 1 \mathrm{H}, \mathrm{H}-8), 3.57-3.63\left(\mathrm{~m}, 4 \mathrm{H}, 2 \mathrm{CH}_{2} \mathrm{O}\right), 4.36(\mathrm{dd}, \mathrm{AB}$ system $J=14.2 \mathrm{~Hz}, 2 \mathrm{H}, \mathrm{CH}_{2} \mathrm{Ph}$ ), 7.34-7.43 (m, 5H, ArH) ppm. ${ }^{13} \mathrm{C} \mathrm{NMR}$ for the imino form $\mathrm{C}: \delta_{\mathrm{C}}\left(125 \mathrm{MHz} ; \mathrm{CDCl}_{3}, \mathrm{Me}_{4} \mathrm{Si}\right)$ $24.8\left(\mathrm{CH}_{2}\right), 27.4\left(\mathrm{CH}_{2}\right), 37.8\left(\mathrm{CH}_{3}\right), 51.0\left(\mathrm{CH}_{2}\right), 61.0\left(\mathrm{CH}_{2}\right), 62.8$ $(\mathrm{CH}), 64.1(\mathrm{CH}), 67.5\left(\mathrm{CH}_{2}\right), 70.3(\mathrm{CH}), 128.6(\mathrm{CH}), 131.2(\mathrm{CH})$, $188.6(\mathrm{C}=\mathrm{N})$; ${ }^{13} \mathrm{C} \mathrm{NMR}$ for the enamino form $7: \delta_{\mathrm{C}}(125 \mathrm{MHz}$; $\left.\mathrm{CDCl}_{3}, \mathrm{Me}_{4} \mathrm{Si}\right) 28.9\left(\mathrm{CH}_{2}\right), 29.5\left(\mathrm{CH}_{2}\right), 33.9\left(\mathrm{CH}_{2}\right), 34.8\left(\mathrm{CH}_{3}\right)$, $44.9\left(\mathrm{CH}_{2}\right), 49.2\left(\mathrm{CH}_{2}\right), 55.8(\mathrm{CH}), 57.3(\mathrm{CH}), 60.8\left(\mathrm{CH}_{2}\right), 67.2$ $\left(\mathrm{CH}_{2}\right), 122.8(\mathrm{C}), 128.1(\mathrm{CH}), 128.3(\mathrm{C}), 130.0(\mathrm{CH}), \quad m z$ 378 $\left(\mathrm{M}^{+}\right)$. Found: C, 60.2; H, 7.4; N, 11.1 calcd. for $\mathrm{C}_{19} \mathrm{H}_{27} \mathrm{~N}_{3} \mathrm{O}_{3} \mathrm{~S}$ C, 60.4; H, 7.2; N, 11.1 .

\section{Acknowledgements}

The authors are grateful to MIUR for financial support through the "FIRB - Programma "Futuro in Ricerca"" grant no. RBFR087YAY and to the "Centro Interuniversitario Lombardo per l'Elaborazione Automatica" (CILEA, Segrate, MI) for computational facilities. We also thank Dr Luca Basolo for the useful discussion upon the Bader's Atom in Molecules theory.

\section{References}

1 (a) For general applications, see:S. R. S. S. Kotti, C. Timmons and G. Li, Chem. Biol. Drug Des., 2006, 67, 101-114; (b) C. A. de Parrodi and E. Juaristi, Synlett, 2006, 2699-2715; (c) D. Lucet, T. Le Gall and C. Mioskowski, Angew. Chem., Int. Ed., 1998, 37, 2580-2627.

2 (a) S. Hashiguchi, A. Fujii, J. Takehara, T. Ikariya and R. Noyori, J. Am. Chem. Soc., 1995, 117, 7562-7563; (b) K. Matsumura, S. Hashiguchi, T. Ikariya and R. Noyori, J. Am. Chem. Soc., 1997, 119, 8738-8739; (c) D. Sterk, M. S. Stephan and B. Mohar, Tetrahedron Lett., 2004, 45, 535-537; (d) D. M. Tellers, M. Bio, Z. J. Song, J. C. McWilliams and Y. Sun, Tetrahedron: Asymmetry, 2006, 17, 550-553.
3 N. Ferri, A. Corsini, P. Bottino, F. Clerici and A. Contini, J. Med. Chem., 2009, 52, 4087-4090.

4 (a) R. Fusco, G. Bianchetti and D. Pocar, Gazz. Chim. Ital., 1961, 91, 933-957; (b) R. Fusco, G. Bianchetti, D. Pocar and R. Ugo, Chem. Ber., 1963, 96, 802-812; (c) F. Cassani, G. Celentano, E. Erba and D. Pocar, Synthesis, 2004, 1041-1046; (d) E. Beccalli, A. Contini and P. Trimarco, Tetrahedron Lett., 2004, 45, 3447-3449; (e) E. M. Beccalli, A. Contini and P. Trimarco, Tetrahedron, 2005, 61, 4957-4964.

5 (a) E. Erba, G. Mai and D. Pocar, J. Chem. Soc., Perkin Trans. 1, 1992, 2709-2712; (b) M. Battistini, E. Erba and D. Pocar, Synthesis, 1992, 1206-1208; (c) E. Erba, D. Pocar and P. Trimarco, J. Chem. Soc., Perkin Trans. 1, 1998, 3535-3539; (d) M. Battistini, E. Erba and D. Pocar, J. Chem. Soc., Perkin Trans. 1, 1993, 339-342; (e) E. M. Beccalli, A. Contini and P. Trimarco, Eur. J. Org. Chem., 2003, 3976-3984.

6 D. Pocar, L. M. Rossi, R. Stradi and P. Trimarco, J. Chem. Soc., Perkin Trans. 1, 1977, 2337-2340and personal communication.

7 B. D. Wladkowski, R. H. Smith Jr. and C. J. Michejda, J. Am. Chem. Soc., 1991, 113, 7893-7897.

8 D. S. Reddy, W. R. Judd and J. Aubé, Org. Lett., 2003, 5, 3899-3902.

9 (a) E. M. Beccalli, G. Broggini, A. Contini, I. De Marchi, G. Zecchi and C. Zoni, Tetrahedron: Asymmetry, 2004, 15, 3181-3187; (b) A. Contini, D. Nava and P. Trimarco, J. Org. Chem., 2006, 71, 159-166; (c) A. Contini, S. Leone, S. Menichetti, C. Viglianisi and P. Trimarco, J. Org. Chem., 2006, 71, 5507-5514; (d) E. Borsini, G. Broggini, A. Contini and G. Zecchi, Eur. J. Org. Chem., 2008, 2808-2816; (e) M. C. Aversa, A. Barattucci, P. Bonaccorsi and A. Contini, J. Phys. Org. Chem., 2009, 22, 1048-1057; (f) F. Gassa, A. Contini, G. Fontana, S. Pellegrino and M. L. Gelmi, J. Org. Chem., 2010, 75, 7099-7106; (g) A. Casoni, E. Borsini, A. Contini, A. Ruffoni, S. Pellegrino and F. Clerici, Curr. Org. Chem., 2011, 15, 3514-3522.

10 Y. Zhao and D. G. Truhlar, J. Phys. Chem. A, 2004, 108, 6908-6918.

11 (a) A. Klamt and G. Schüürmann, J. Chem. Soc., Perkin Trans., 1993, 2, 799-805; (b) J. Andzelm, C. Kölmel and A. Klamt, J. Chem. Phys., 1995, 103, 9312-9320; (c) V. Barone and M. Cossi, J. Phys. Chem. A, 1998, 102, 1995-2001; (d) M. Cossi, N. Rega, G. Scalmani and V. Barone, J. Comput. Chem., 2003, 24, 669-681.

12 C. Gonzalez and H. B. Schlegel, J. Chem. Phys., 1989, 90, 2154-2161.

13 Y. Lan, L. Zou, Y. Cao and K. N. Houk, J. Phys. Chem. A, 2011, 115, 13906-13920.

14 K. B. Wiberg, Tetrahedron, 1968, 24, 1083-1096.

15 (a) Natural bond orbitals:A. E. Reed, L. A. Curtiss and F. Weinhold, Chem. Rev., 1988, 88, 899-926; (b) A. E. Reed, L. A. Curtiss and F. Weinhold, J. Chem. Phys., 1985, 83, 735-746.

16 R. F. W. Bader, Atoms in molecules: A quantum theory, Clarendon Press, Oxford, 1994.

17 (a) E. A. B. Kantchev, Chem. Commun., 2011, 47, 10969-10971; (b) Y. Shen, Q. Meng, S. Huang, S. Wang, J. Gong and X. Ma, RSC Adv., 2012, 2, 7109-7119.

18 R. F. W. Bader, Chem. Rev., 1991, 91, 893-928.

19 MOE V. 2010.10, Chemical Computing Group Inc., Montreal, Canada, http://www.chemcomp.com..

20 Gaussian 09, Revision A.1,M. J. Frisch, G. W. Trucks, H. B. Schlegel, G. E. Scuseria, M. A. Robb, J. R. Cheeseman, G. Scalmani, V. Barone, B. Mennucci, G. A. Petersson, H. Nakatsuji, M. Caricato, X. Li, H. P. Hratchian, A. F. Izmaylov, J. Bloino, G. Zheng, J. L. Sonnenberg, M. Hada, M. Ehara, K. Toyota, R. Fukuda, J. Hasegawa, M. Ishida, T. Nakajima, Y. Honda, O. Kitao, H. Nakai, T. Vreven, J. A. Montgomery Jr., J. E. Peralta, F. Ogliaro, M. Bearpark, J. J. Heyd, E. Brothers, K. N. Kudin, V. N. Staroverov, R. Kobayashi, J. Normand, K. Raghavachari, A. Rendell, J. C. Burant, S. S. Iyengar, J. Tomasi, M. Cossi, N. Rega, J. M. Millam, M. Klene, J. E. Knox, J. B. Cross, V. Bakken, C. Adamo, J. Jaramillo, R. Gomperts, R. E. Stratmann, O. Yazyev, A. J. Austin, R. Cammi, C. Pomelli, J. W. Ochterski, R. L. Martin, K. Morokuma, V. G. Zakrzewski, G. A. Voth, P. Salvador, J. J. Dannenberg, S. Dapprich, A. D. Daniels, Ö. Farkas, J. B. Foresman, J. V. Ortiz, J. Cioslowski and D. J. Fox, Gaussian, Inc., Wallingford CT, 2009.

21 F. Biegler-König, J. Schönbohm and D. Bayles, J. Comput. Chem., 2001, 22, 545-559.

22 R. Fusco, G. Bianchetti and S. Rossi, Gazz. Chim. Ital., 1961, 91, 825-840.

23 E. Vilsmaier, T. Herweck, M. Schummel, C. Tetzlaff, M. Dotzauer and U. Bergsträßer, Tetrahedron, 1998, 54, 7401-7416. 